\title{
Ćudoredno neprihvatljive intervencije protiv spolne sposobnosti osoba s intelektualnim teškoćama
}

Ante Komadina*

\begin{abstract}
Sažetak
U svjetlu kršćanske antropologije i etike razmatraju se pojedine kompleksne situacije u vezi sa spolnim i čuvstvenim životom osoba s intelektualnim teškoćama. Riječ je o životnim situacijama s kojima se u svakodnevnom životu sučeljavaju roditelji i odgajatelji osoba s intelektualnim teškoćama. Ta je tema nezaobilazna također $i$ za širu društvenu zajednicu. U perspektivi kršćanskog ćudorednog nauka obrađuju se „dvojbene situacije“, posebice u vezi s kirurškom sterilizacijom osoba s intelektualnim teškoćama, koja se provodi kako bi se favorizirao seksualni liberalizam i izbjeglo nasljeđe eventualnih patoloških stanja. Porast seksualnog nasilja povlači također za sobom pitanje „zaštite“ osoba s intelektualnim teškoćama uz pomoć kontracepcijskih sredstava. Obrađujući tu problematiku istaknuli smo kontradiktorne pozicije, kao i postojanje rubnih situacija $i$ svih dvojbi u vezi s njima. Zaključili smo kako socijalno svjesno civilno društvo treba svakoj fizički i posebice mentalno nerazvijenoj osobi pružiti adekvatnu skrb i zaštitu, koliko god to u socijalnom i gospodarskom smislu bilo zahtjevno. Kvaliteta društva mjeri se prema zauzimanju i skrbi članova, a posebice odgovornih tog društva, za najslabije i za one koji su najpotrebniji naše pomoći.

Ključne riječi: osoba s intelektualnim teškoćama, spolni i čuvstveni život, kirurška sterilizacija, kontracepcija
\end{abstract}

\section{Uvod}

U ovom članku namjeravamo u svjetlu kršćanske antropologije i u perspektivi kršćanske etike istaknuti neka žarišta problematike koja je povezana s čuvstvenim i spolnim životom osoba s intelektualnim teškoćama. Činjenica je da se o spolnom životu mentalno nerazvijenih ili bolesnih osoba vrlo malo i oskudno govori i piše. Tu se temu najradije izbjegava, zaobilazi, zatvara se oči pred njom

* Doc. dr. Ante Komadina, Katehetsko-teološki institut u Mostaru. Adresa: Zagrebačka 5A, 88000 Mostar, Bosna i Hercegovina. E-pošta: caritas-mostar@tel.net.ba 
ili se jednostavno gurne pod tepih. Uglavnom je to posljedica nerazumijevanja i nespremnosti uže i šire društvene zajednice da se sučeli s tom vrlo kompleksnom problematikom. Ako se netko u ne tako dalekoj prošlosti tom temom i pozabavio, onda je to, prema mišljenju suvremenih znanstvenika, gotovo redovito bilo površno, neprimjereno ili čak ideološki obojeno. Nerijetko se spolna dimenzija osoba s intelektualnim teškoćama reducirala na područje genitalnosti.

Prije nego što započnemo s konkretnijim analizama, želimo istaknuti uvjerenje kako ne postoje dimenzije ljudske osobe rezervirane i karakteristične za osobe s i bez intelektualnih teškoća. Dostojanstvo ljudske osobe je prepoznatljivo i vrijedno bezuvjetnog poštovanja bez obzira na psihofizičke osobine, sposobnosti ili nedostatke pojedinca. Analogno tomu, ne postoji spolnost koja bi se po svojim osobitostima mogla pripisati isključivo tzv. normalnima. Naravno da kod osoba s intelektualnim teškoćama postoji određeni stupanj uvjetovanosti ograničenosti u izvršavanju i aktualiziranju temeljnih ljudskih vrijednosti u usporedbi sa psihofizički razvijenim osobama. Upravo ta mentalna i fizička uvjetovanost osoba s invaliditetom zahtijeva, posebice na području njihove seksualnosti, suptilniju analizu i interpretaciju.

\section{Psihosomatski integritet $i$ dostojanstvo ljudske osobe}

Činjenica je da poremećaji u razvoju, bili oni tjelesni ili mentalni, nikada nisu izolirani. Ne postoje, naime, jedino i isključivo mentalne poteškoće u razvoju, ili samo i jedino fizičke. Svaka povrjeda tjelesnog integriteta ili nedostatak somatske funkcionalnosti odražava se također i na psihu, jer uvjetuje percepciju vlastite tjelesnosti i narušava stabilnost vlastitog integriteta. Istodobno se također pojavljuju poteškoće ili se čak sprječava uspostavljanje odnosa s drugima. Isto tako svaki nedostatak na psihičkoj razini reflektira se na poimanje vlastite tjelesnosti i fizičkog integriteta, te na postojanje u svijetu, kao i na uspostavljanje odnosa s drugima. Sve to utječe također na izgradnju osobnosti i vlastitog identiteta.

Tijelo, dakle, postaje svojevrsno križište u kojem se susreću i isprepliću razne dimenzije ljudske osobe koja ih u svojem totalitetu povezuje i objedinjuje. Tu se ne misli na tijelo kao objekt, nego tjelesnost koja se živi, na tijelo osobe, na tijelo sjedinjeno s ljudskim duhom, na tijelo u kojem i po kojem jesmo i postojimo. Upravo se po tijelu svaki subjekt očituje i predstavlja u određenom prostoru i vremenu te se po njemu ostvaruju interpersonalni odnosi.

Ljudsko je tijelo istodobno obilježeno spolnom dimenzijom, prožeto i determinirano u sebi specifičnim oblikom postojanja kao muškarac ili kao žena. Uistinu, muževnost i ženstvenost ne mogu se proniknuti u svojem dubokom značenju ako ih se promatra samo kroz njihove biološke ili psihičke komponente. Dokučiti i djelomično shvatiti tajnu postojanja kao žena ili kao muškarac moguće je kroz njihovu interpersonalnu usmjerenost kojom su po svojoj naravi obilježeni, odnosno kroz ostvarivanje recipročnih odnosa, susreta dvaju bića koja se nadopunjuju i međusobno darivaju u osobnom i tjelesnom smislu. Upravo je tjelesnost ta koja otkriva iskonsku ljudsku usmjerenost: muškarac i žena egzisti- 
raju u svojoj raznolikosti da bi se mogli susresti u svojoj recipročnosti. Prvotno i duboko značenje ljudske spolnosti razotkriva također konačnu svrhu ljudskog postojanja: autotranscendenciju. To je ustvari sebedarje, izići iz sebe da bi susreo drugoga, otvoriti se zajedništvu u potpunosti, ekskluzivnosti i vjernosti, kojemu nije svrha samo supružništvo, nego je također otvoreno prokreaciji. Autentično prakticiranje seksualnosti, dakle, ne znači tražiti isključivo i jedino vlastito dobro i ugođaj, nego ono uvijek pretpostavlja i nerazdvojivo je od spremnosti i iskrene želje da se također ugodi drugomu. Popratno zadovoljstvo koje se osjeća ustvari je plod isprepletenosti i recipročnosti interpersonalnog odnosa (Ortland, 2008, 16-23; Castelli, 2005, 14s i 153s).

Ljudska je spolnost konstitutivna sastojnica ljudske osobe i tiče se cijele osobe. Ona prožima cijelu osobu, čitav osobni „ja“. Spolnost, dakle, predstavlja jedan od temeljnih elemenata osobnog identiteta, koji je određen biološkim, psihološkim i duhovnim sastojnicama. To čvrsto jedinstvo psihofizičkog u čovjeku razlog je što svaka od tih komponenti zahvaća čovjeka u dubini njegova bića. Zato spolnost utječe na čovjeka tako duboko i obilježava svakog pojedinca na biološkom, psihološkom i duhovnom planu, čineći ga muškarcem ili ženom i značajno utječući na tijek sazrijevanja svake osobe i na njezino uključivanje u društvo. Kao konstitutivna dimenzija osobe, ljudska je spolnost također polivalentna jer se odnosi na tjelesne (eros), psihičke (filia) i duhovno-religiozne (agape) vrijednosti. Spolnost je, dakle, način postojanja. Nije to povremeno i kratkoročno izvršavanje nekih funkcija, nego trajni način postojanja koje prepoznajemo kao muškost ili ženskost. Izvršavanje spolnosti jedino i isključivo genitalnim činima ne predstavlja sve esencijalne sadržaje i vrijednosti ljudske spolnosti, nego postaje sporedni ljudski čin (Lucas Lucas, 2007, 35-36).

Razvidno je, dakle, da je i ljudska spolnost podložna svim zakonitostima razvoja i sazrijevanja ljudske osobe. Ne može se ni zamisliti druga mogućnost spolnog odgoja, ako se nema pred očima sva kompleksnost cjelovitog odgojnog procesa. Naime, sve ono što narušava, ometa ili sprječava odgojne procese u cjelini, odražava se automatski i na spolnost ljudske osobe. Ne može biti odgoja za čistoću i neporočnost ako se u širem kontekstu nije dovoljno pažnje posvetilo intelektualnomu odgoju te disciplini volje i čuvstvenog života, što čovjeka čini otvorenim ne samo za naravne nego i nadnaravne vrijednosti. Samo takav cjelovit odgoj polučit će zreo unutarnji stav shvaćanja i prihvaćanja te radosnog doživljavanja i svakodnevnog življenja vlastite spolnosti kroz autentičnu ljubav (Rovatti, 2016, 15s; 41s; 59s).

Kod osoba s intelektualnim teškoćama, unatoč kompleksnosti i slojevitosti psihosomatskih uvjetovanosti i međuovisnosti, spolna dimenzija predstavlja također konstitutivni element njihove osobnosti. Premda je seksualnost osoba s intelektualnim teškoćama životna stvarnost i specifičan doživljaj subjekta koji je nerazvijen i višestruko ranjiv, ona se ne očituje i ne predstavlja na uobičajen, nego na drugačiji i poseban način. Upravo zbog svoje specifičnosti te ranjivosti i intelektualnih poteškoća subjekta u izuzetnim i vrlo rijetkim slučajevima njihova je spolnost usmjerena prema postizanju veće zrelosti. U idealnom smislu 
čuvstveno-seksualni odgoj osoba s intelektualnim teškoćama ima isti ćudoredni cilj kao i odgoj intelektualno razvijene osobe, jer ne postoji zaseban odgojni cilj u moralnom smislu o ljudskoj spolnosti za osobe s mentalnim invaliditetom od onog za mentalno razvijene osobe. Spolni odgoj ne prestaje završetkom dječačke i adolescentske dobi, nego naprotiv osobu s intelektualnim teškoćama treba nastaviti usmjeravati na području seksualnosti i u odrasloj dobi, odnosno permanentno je pratiti kroz cijeli život (Mariani, 2005, 257).

Cilj je odgoja za ljubav da osobe $s$ intelektualnim teškoćama usmjeravaju svoje seksualne potrebe u pravcu dobro definiranog odnosa koji ima izrazito čuvstveni profil i na taj način ih, unatoč brojnim poteškoćama i bezuvjetnoj ustrajnosti da se to postigne, osposobljavati da prepoznaju vrijednost međusobne čuvstvene povezanosti, što se očituje kroz konkretne geste ljubavi. Odgajati za ljubav znači prije svega odgajati za brižnu skrb o drugome i dopustiti istodobno da se drugi brine o meni. Uspostaviti pravu povezanost i međusobnu prožetost između čuvstvenosti, spolnosti i otvorenosti životu implicira kako svaka manifestacija ljubavi treba biti smještena u životnu logiku ujedinjavanja i zajedništva. Ta ujedinjujuća čuvstvena povezanost pruža stabilnost psihičkoj ravnoteži, koja može biti poremećena nekontroliranim i neprimjerenim ponašanjem. Težiti dati smisao čuvstvenomu životnomu iskustvu znači također priznati objektivnost međusobnoj privlačnosti i čežnjama bez da ih se banalizira, mijenjajući sugovornika svaki put kad se pojavi neka poteškoća ili teško prihvatljiv poremećaj kod drugoga (Mariani, 1992, 59-66).

Čuvstveni i spolni odgoj osoba s intelektualnim teškoćama polazi od pretpostavke kako svaka osoba s invaliditetom ima potrebu za ljubavlju isto onoliko koliko i svaka druga osoba. Osoba s intelektualnim teškoćama također želi ljubiti i biti ljubljena, osjeća potrebu za nježnošću, za blizinom i intimnošću. No, budući da je sputana i spriječena svojim intelektualnim teškoćama, ona nije u stanju te svoje legitimne i naravne potrebe za nježnošću i ljubavlju živjeti i ostvarivati, pogotovo jer njezino mentalno zdravlje i umanjena sposobnost ostvarivanja interpersonalnih odnosa ostaje nepromjenjiva, a s napredovanjem tjelesne zrelosti svijest o sebi te intelektualne i čuvstvene sposobnosti ostaju nerazvijene. Osoba s intelektualnim teškoćama, bez obzira na svoju adolescentsku, mladenačku ili odraslu dob, mentalno nerazvijena te ranjiva s neizgrađenim i poremećenim interpersonalnim dimenzijama, u potrazi je za autentičnim, iskrenim odnosima kroz koje će se osjećati cijenjena i poštovana kao osoba (Ivan Pavao II., 2007, br. 5).

Naime, psihoseksualni razvoj odrasle osobe s intelektualnim teškoćama, posebice s težim stupnjem, obilježen je konkretnim ograničenjima, kako perceptivnim, tako i prosudbenim te izričajnim i komunikativnim. Dakle, riječ je o relacijskim poremećajima sa svijetom oko sebe i s drugima. Ti relacijski poremećaji negativno utječu na njegov redovit i uredan psihološki razvoj, čak i onda kad se nalazi u ambijentu u kojem se osjeća prihvaćen i sretan. Činjenica je da osoba s intelektualnim teškoćama, ovisno o tome je li riječ o lakim, umjerenim ili težim teškoćama, uglavnom nije u potpunosti autonomna, nego joj je tijekom 
cijelog njezina života potrebna i nužna pratnja i skrb. Poglavito osoba s težim intelektualnim teškoćama uslijed svoje mentalne ograničenosti nije sposobna preuzeti elementarne konkretne odgovornosti u svakodnevnom životu. U težim slučajevima kod pojedinaca nedostaje samosvijest. Dakle, posve nedostaje ili je poremećena svijest o sebi, o svojem ,ja“, o vlastitoj individualnosti. Ne prepoznaje i ne shvaća svoj osobni identitet i ne uspijeva dokučiti i proniknuti ovdje i sada stvarnost u kojoj živi (Mariani, 1992, 12-15).

Razumske i voljne sposobnosti osoba s intelektualnim teškoćama ograničene su i to posve, znatno ili u manjoj mjeri. To ih čini manje sposobnima i prikladnima za bilo koji oblik bračnog ujedinjavanja s osobom drugog spola, što ne znači da je to u crkveno-pravnom i moralnom smislu nedopustivo, ovisno o kojem je stupnju intelektualne nerazvijenosti riječ. Upravo zbog toga osobe s težim intelektualnim teškoćama ne posjeduju svijest ni o temeljnim vrijednostima takvog odnosa ni o obvezama koje iz takvog odnosa proizlaze. Mentalna ograničenost utječe, odnosno čini ih manje ili posve nesposobnima za razmišljanje i planiranje obiteljskog života, da svjesno rađaju i odgajaju djecu, odnosno da budu u cijelosti osobno odgovorni za maleno biće koje bi došlo na svijet i o kojem oni trebaju skrbiti (Mariani, 2005, 257-261).

Osoba s intelektualnim teškoćama, dakle, nema punu svijest i znanje o vrijednosti, značenju i posljedicama spolnog odnosa. Takvoj osobi nedostaje također u određenoj mjeri sposobnost da se obrani od instrumentaliziranja i manipuliranja jer joj, zbog unutarnjih psihičkih poremećaja i ograničenja, nedostaje puni osjećaj stida koji bi joj pomogao i potaknuo je na obranu od svih onih koji u njoj vide samo predmet za zadovoljenje svoje seksualne požude. Takvo ćudoredno iskrivljeno poimanje spolnog odnosa zaustavlja se isključivo na zadovoljenju seksualnog nagona, u kojem posve nedostaje ona divna dimenzija međusobnog darivanja.

Osoba s posebnim potrebama, pogotovo s intelektualnim ograničenjima i teškoćama, bez obzira na dob — adolescent, mladić, odrastao — budući da je ranjiva u srcu i ograničena u sposobnostima uspostavljanja odnosa, također čezne za uspostavljanjem autentičnog odnosa u kojem će biti cijenjena i poštovana kao osoba. U tim osobama postoji velika želja za autentičnom čuvstvenošću, nježnošću, za ljubavlju. One to često manifestiraju kroz želju i geste fizičkog dodira, zagrljaja, milovanja, što ne uključuje želju za spolnim odnosom, nego sve te potrebe prepoznatljive u gestama treba shvatiti i tumačiti u njihovu dubljem značenju, tj. kao poziv upućen drugomu, čežnja za drugom osobom, želja za uspostavljanjem odnosa. Nažalost odgovori društva i uže sredine na tu delikatnu stvarnost ne respektiraju uvijek osobu s posebnim potrebama, poglavito se to odnosi na osobu s težim intelektualnim teškoćama, u njezinoj stvarnoj posebnosti i ograničenosti (Faggioni, 2007, 113-114). 


\section{Sterilizacija osoba s intelektualnim teškoćama}

Čuvstveni i seksualni život i odnosi što ih žive osobe pogođene mentalnim hendikepom potiču izrazito delikatna pedagoška i etička pitanja. Posebice kada je riječ o osobama koje imaju normalno razvijene genitalne organe i spolne sposobnosti, njihove eventualne spolne aktivnosti nisu srazmjerne njihovim umanjenim intelektualnim sposobnostima. Unatoč svojoj fizičkoj spolnoj potentnosti, osobe s intelektualnim teškoćama pokazuju velika čuvstvena ograničenja, poglavito u uspostavljanju i održavanju zrelih čuvstvenih odnosa s osobama suprotnog spola, kao i u preuzimanju odgovornosti koje su temeljne i svojstvene normalnomu supružničkomu odnosu. Te osobe, osim terapije koju trebaju uzimati zbog svojeg mentalnog oboljenja, trebaju također asistenciju kroz strpljivu, odgojnu, individualnu terapiju koja, naravno, isključuje svaku marginalizaciju. Takav odgojni pristup i metode pomoći će im u sazrijevanju ili, u najmanju ruku, u postizanju čuvstvene i mentalne ravnoteže, jer je njihovo stvarno stanje obilježeno neskladom fizičke spolne sposobnosti s jedne strane te spolnosti koju stvarno žive s druge strane.

Neki auktori zagovaraju posve drugačiji pristup i metode odgoja u vezi sa spolnosti osoba s mentalnim hendikepom (Ortland, 2008, 85s; Reynolds, 2014, 43-63; An., 1998, 6-12; Dixon, 1990, 81s i 113s; Bratković, 2000, 24-32; Bratković i Bilić, 2004). Njihov se stav temelji na poistovjećivanju ljudske spolnosti s genitalnošću i brkaju pravu slobodu s instinktivnošću. Dosljedno tomu redukcionističkomu poimanju ljudske spolnosti zagovaraju odgojne tečajeve u kojima je na prvom mjestu seksualni užitak i „socijalizirajuća dimenzija“ fizičke spolnosti. Dakle, zanemaruje se preuzimanje odgovornosti za interpersonalnu dimenziju ljudske spolnosti. Inzistira se na tome da osobe s intelektualnim teškoćama imaju spolne odnose jer, kako kažu, potiču razvoj ljudskih potencijala, iako se istodobno čini sve da se na najučinkovitiji način spriječi začeće, odnosno da postanu roditelji, bilo zbog njihove nesposobnosti da skrbe i odgajaju djecu, bilo zbog poimanja plodnosti kao elementa koji nepotrebno i parazitski sputava slobodno iskazivanje erosa.

Naravno, da se u takvom pseudopedagoškom ozračju redovito savjetuje uporaba kontracepcijskih sredstava kako ne bi došlo do neželjene trudnoće, a vrlo se često pribjegava i kirurškoj sterilizaciji kao konačnomu i sigurnomu rješenju problema plodnosti osobe s intelektualnim teškoćama. U slučajevima genetski pretpostavljene ili utvrđene intelektualne patologije pribjegava se, iz tzv. eugeničkih pobuda, također kirurškoj sterilizaciji kao najsigurnijoj metodi s ciljem sprječavanja rađanja potomstva koje bi prenosilo genetske patologije.

O tim postupcima katolička moralka ima jasan stav. Papa Pio XII. još je davne 1953. u govoru sudionicima Međunarodnog simpozija medicinske genetike, kad još nije bilo izblijedjelo sjećanje na nacističke eugeničke metode, podsjetio na smjernice koje je proglasio njegov prethodnik papa Pio XI. Potvrđujući njegov nauk, Pio XII. proglasio je protivnom Božjemu naravnomu zakonu ne samo eugeničku, nego i svaku drugu sterilizaciju nevinog ljudskog bića, bez obzi- 
ra bila ona privremena ili konačna. Crkva zastupa i danas to načelo, jer unatoč činjenici da većina ondašnjeg, a pogotovo suvremenog svijeta odbacuje i osuđuje nacističke rasističke metode, ipak još uvijek ima takvih koji uz pomoć sterilizacije žele ukloniti svaku mogućnost širenja nasljednih bolesti (Faggioni, 2007, 116).

Prema naravnomu Božjemu zakonu, čiji glas odjekuje u čovjekovoj savjesti, nedopustiv je svaki čin koji ometa i sprječava sposobnost rađanja. Po zakonitostima svoje naravi, svaki čovjek dužan je braniti vlastiti psihofizički integritet i odlučno ustati u zaštitu osobnog integriteta svakog čovjeka. U konačnici to je također obrana cjelovite istine o ljudskoj spolnosti. Bezuvjetna obrana integriteta osobe je još očitija i nužnija kada se raskrinkaju pravi razlozi nasilničke naravi kirurške sterilizacije. Kirurška sterilizacija predstavlja, naime, izravno ranjavanje osobnog integriteta osobe s intelektualnim teškoćama i nepovratno ju onesposobljuje za rađanje — prenošenje života — što je svakako najplemenitija ljudska sposobnost. Osoba pogođena najprije mentalnim hendikepom biva potom pogođena i tom vrstom nepravde, dakle, nasilno osakaćena, a osim toga redovito nema mogućnosti ni snage braniti se od takvog nasilja, što daje dodatni pečat okrutnosti tomu činu.

Činjenica je također da za osobe s intelektualnim teškoćama sterilizirajući interventi, a isto vrijedi i za kontracepciju, nisu od koristi ni u medicinskom ni u pedagoškom smislu. Naprotiv, takva je osoba u još većoj opasnosti da bude ponižena i povrijeđena u svojem dostojanstvu, jer je još izloženija napastovanjima, seksualnomu nasilju i iskorištavanju, ne isključujući također u ekstremnim slučajevima poticanje na prostituciju. Osim toga, gotovo sigurno će izostati, odnosno čak će se smatrati beskorisnom, ona važna pedagoška personalizirajuća podrška, koju su praktično zamijenile sterilizacija, odnosno kontracepcija. Svemu tomu treba pribrojati također i sve druge rizike koji su povezani s neodgovornim i nemoralnim genitalnim aktivnostima, poglavito se misli na infekciju HIV-om, od koje ne može zaštiti ni sterilizacija ni kontracepcija.

Doista, osoba s mentalnim teškoćama na kojoj je izvršena kirurška sterilizacija ili je prisiljena na uzimanje kontracepcijskih sredstava, nema od svih tih intervencija doslovno nikakve „koristi“. Korist u ekonomskom smislu ima isključivo društvena zajednica, koja uz pomoć tih metoda sprječava eventualna začeća i trudnoće te ne mora tim osobama pružati potporu u još složenijim situacijama. Isto tako, ako se utvrdi da postoji opasnost od genetički prenosivih bolesti, onda je sterilizacija osoba s intelektualnim teškoćama dobrodošla, jer se sprječava nastajanje novih generacija, odnosno povećavanje populacije koja je neproduktivna i skupa za društvo. Naravno, takav je stav nepomirljiv s opće priznatim etičkim načelima poštovanja dostojanstva ljudske osobe, njezinih neotuđivih prava, integriteta i autonomnosti (Faggioni, 2007, 117-118).

Ako, međutim, državne strukture ne pružaju adekvatnu skrb osobama s intelektualnim teškoćama, nego ih zanemaruju ili čak iz sebičnih materijalnih razloga gaze njihovo ljudsko dostojanstvo i prijetnja su za njihov psihofizički integritet, društva, dakle, koja ne respektiraju temeljna prava najranjivije populacije i svoje obveze prema njima, onda se u takvim društvima sterilizacija osoba s mentalnim 
poremećajima shvaća i opravdava kao manje zlo, odnosno smatra je se jedinim praktičnim i nadasve učinkovitim rješenjem. Ali ako dobronamjerno društvo, koje je socijalno osjetljivo, cijelu problematiku promatra u svjetlu ljudskih prava, onda će u toj specifičnoj situaciji, koju je vrlo često teško nadzirati, radije, umjesto što će posegnuti za sterilizacijom, smjestiti osobu s intelektualnim teškoćama u specijaliziranu ustanovu ili će započeti s pripremama za izgradnju primjerenih struktura za potporu i pomoć tim osobama.

Tu ipak želimo istaknuti kako naš stav o ćudorednoj neprihvatljivosti i nedopustivosti sterilizacije i kontracepcije, što neki zagovaraju (čak i roditelji, staratelji) u vezi sa spolnim aktivnostima svakodnevnog ponašanja osoba s intelektualnim teškoćama (masturbacija, slobodni spolni odnosi ako su zaštićeni itd.), ne znači da nismo svjesni ili da zatvaramo oči pred složenom činjenicom nedostatka ili potpunog izostanka zrelosti osoba sa psihičkim poremećajima. Kirurška sterilizacija, kao i kontracepcija, obje gotovo redovito prisilne, ne samo što ne predstavljaju humano, pravedno i etički korektno rješenje, nego štoviše često su uzrok mnogo težih negativnih posljedica zadajući duboke rane dostojanstvu i integritetu osoba s intelektualnim teškoćama.

Katolička crkva nema poseban ćudoredni nauk za intelektualno razvijene i zrele osobe, a neki drugi, malo ili posve drugačiji za osobe s intelektualnim teškoćama, odnosno za osobe koje su dostignule genitalnu, ali ne i intelektualnu i emocionalnu zrelost. Poziv na svetost i na spasenje koje nam je Krist uputio uključuje sve ljude bez diskriminacije: muževe i žene, mlade i stare, bogate i siromašne, intelektualce i nepismene, zdrave i bolesne. Crkva sve njih podsjeća i kroz minula tisućljeća poučava kako se ćudoredno dobro, kada je riječ o spolnom sjedinjenju, ostvaruje isključivo u prokreativnom sjedinjenju muškarca i žene koji su vezani sakramentom braka, a ne u nekakvoj vezi u kojoj se događa samo genitalno sjedinjenje muškarca i žene bez osobnog, svjesnog i slobodnog, recipročnog darivanja u ljubavi.

Svi oni koji zagovaraju nametanje kontracepcije i kirurške sterilizacije osobama s intelektualnim teškoćama, koliko se god njihov stav činio humanim, ipak je riječ o stavu kojim se na jednoj strani želi opravdati nasilje nad osobama s intelektualnim teškoćama, a na drugoj strani razotkriva se hedonistička ukorijenjenost tog stava. Bez obzira na ćudorednu neprihvatljivost tih intervencija koje osobe s intelektualnim teškoćama čine neplodnim, nehumano je po kratkom postupku onesposobiti za roditeljstvo i rađanje osobe koje nisu sposobne autonomno upravljati svojim životom i kontrolirati svoju seksualnost. Kao što ne bi bilo istinoljubivo o osobi s invaliditetom prikrivati njezinu umanjenu sposobnost da živi svoju seksualnost, tako isto bi se protivilo istini tvrditi da se umanjena mentalna sposobnost ne odražava na tijelo, kako bi se tjelesni život živio bez tegoba. U svakom slučaju, stav koji prakticiranje isključivo genitalne spolnosti smatra humanim i posve prihvatljivim možemo nazvati redukcionističkom antropologijom, po kojoj se ljudska seksualnost svodi na genitalne aktivnosti.

Suvremena zapadna kultura, koja kontracepciju proglašava legitimnom, zanemaruje i antropološko značenje povrjede tjelesnog integriteta osobe, što se 
ustvari događa u činu kirurške sterilizacije. Za zapadnjački svjetonazor našeg doba jedini problem etičko-pravne naravi predstavlja činjenica da te osobe ne mogu, odnosno nisu sposobne slobodno i eksplicitno očitovati svoju suglasnost za takve kirurške intervencije. Doista, upravo nesposobnost slobodnog pristanka na sterilizaciju predstavlja nezaobilaznu i tešku zapreku u pravnom i moralnom smislu za provođenje sterilizacije nad osobama s intelektualnim teškoćama. Naime, ako osoba može odgovorno upravljati svojom seksualnošću, onda ni ne postoji pravno i moralno valjan razlog da je se podvrgne kirurškomu zahvatu oduzimanja sposobnosti rađanja, odnosno sakaćenju. Ako je, međutim, sterilizacija — sakaćenje motivirano nesposobnošću osobe da se odgovorno odnosi prema svojoj seksualnosti, da nije sposobna prepoznati eventualne prijevare, zavođenja i zloporabe te da se od njih brani, onda je apsurdno očekivati da ista osoba može donijeti autonomnu i slobodnu odluku o toj materiji (Henry, 1999, 61-68). Ćudoredno je neprihvatljivo da u ime osobe s intelektualnim teškoćama odluku u njezino ime donose roditelji ili staratelji ili liječnik ili bilo kakvi društveni zakoni i auktoriteti. Takve su intervencije ćudoredno apsolutno neprihvatljive jer predstavljaju povrjedu dostojanstva i integriteta ljudske osobe. Odlučivati u ime nekoga o tako delikatnim životnim pitanjima predstavlja doista neprihvatljiv stupanj paternalizma.

Činjenica je da je sve do šezdesetih spolnost osoba s intelektualnim teškoćama bila shvaćana kao svojevrsni društveni problem. Tradicionalni negativni stavovi te eugenička stremljena bila su razlog negativnomu stavu društva prema tim osobama do te mjere da se čak isticala potreba ,zaštite“ društva od devijantnosti i promiskuiteta osoba s intelektualnim teškoćama (Bratković i Bilić, 2004, 3). U svakom slučaju, ta je problematika pokrenula mnoge te su donesene brojne uredbe i zakoni, posebice o kirurški trajnoj sterilizaciji osoba s intelektualnim teškoćama. U pozadini brojnih legalističkih odredbi mogu se iščitati dva temeljna antropološka i etička usmjerenja (Piana, 1999, 152s):

Na jednoj strani imamo antropologiju i etiku koja zagovara da se osobu s intelektualnim teškoćama usmjeri prema harmoničnomu očitovanju svoje osobnosti, da je se potiče na konstantni razvoj svih svojih sposobnosti koji treba težiti prema uzajamnoj ljubavi i socijalnoj solidarnosti.

Posve su oprečne tomu stavu antropologija i etika prema kojima osobne potencijale, da bi se skladno razvijali, treba projicirati u smjeru postizanja osobnog zadovoljstva, što je u konačnici ipak podređeno društvenoj koristi. U prvoj je postavci poštivanje prava pojedinca privilegirano naspram društvenih i ekonomskih prava zajednice. Međutim, u drugom slučaju prava šire zajednice te ona socijalna i ekonomska s obzirom na prava pojedinca procijenjena su kao izrazito veći i naglašeniji društveni egoizam (Faggioni, 2007, str. 119). 


\section{Izloženost osoba s intelektualnim teškoćama seksualnom nasilju}

Uistinu nije teško zamisliti dramatičnu situaciju osoba s intelektualnim teškoćama kada su izložene opasnosti od seksualnog nasilja. U mnogo slučajeva upravo je intelektualna nerazvijenost razlog tomu da se osoba ne zna obraniti od nasilnika. Nažalost, u mnogim je zemljama fenomen seksualnog nasilja u porastu, a žrtve su gotovo bez iznimke oni najslabiji: djeca, siromašni i socijalno ugroženi, protjerani i izbjeglice, duševni bolesnici i oni s intelektualnim teškoćama, a događa se također i nasilje nad starijim osobama, kao i na mlađim ženama. No, pored fizičkog nasilja i zastrašivanja, postoji također i pritajeno, rekli bismo psihološko nasilje, koje je vrlo česta pojava među mladima i adolescentima. Takvi naizgled pristaju svojevoljno na seksualni odnos, i to potaknuti lošim utjecajem sredstava priopćavanja. U svojoj lakovjernosti budu privučeni raznim obećanjima socijalne, poslovne ili materijalne naravi. Vrlo često žrtve nasilja zbog osobne prirodne potrebe za naklonošću, pažnjom, nježnošću, zbog želje da i oni budu prihvaćeni i voljeni, budu na vrlo lukav i suptilan način zavedeni i prevareni. Prividni pristanak žrtve na seksualne čine nerijetko je zapravo psihološka nezrelost, koja je uzrok tomu da žrtva naivno pristaje na razna lukava uvjetovanja i na čuvstvene plagijate. Teško će se netko odvažiti na definiciju intelektualne ograničenosti, a još manje sa sigurnošću tvrditi da može proniknuti što se krije u „komorama“ njegova u razvoju zastalog intelekta ili razvezati čvorove njegovih emocija ili raskinuti okove njegove sputane volje. Međutim, s velikom se sigurnošću može tvrditi da takve osobe ne posjeduju punu sposobnost razumijevanja i htjenja, ne samo zbog svoje mladenačke dobi, nego i zbog krhkosti i nestabilnosti njihovih čuvstava te također zbog njihove očite nesposobnosti da dokuče sve posljedice seksualnih čina na koje ih nasilnik zavodi.

Seksualno nasilje, bilo ono naizgled i najbezazlenije, predstavlja uvijek najgrublji napad i invaziju na najintimniju sferu ljudske osobe. Silovanje osobe povezano je uvijek s dubokim poniženjem, gaženjem ljudskog dostojanstva, ali is teškom fizičkom povredom, odnosno obeščašćenjem tijela. Upravo zbog samopoštovanja vlastitog identiteta i osobnog dostojanstva čovjek svoje tijelo daruje i izlaže svojevoljno željenoj i voljenoj osobi. Silovatelj naprotiv žrtvu podvrgava vlastitoj požudi, posve je zanemaruje i ne prepoznaje u njoj osobu koja ima svoje potrebe, svoje dostojanstvo, umrtvljujući je u svakom smislu, posebice moralnom. Silovana osoba proživljava ne samo veliki strah, nego i duboki osjećaj poniženja što se s njom postupalo i iskoristilo je kao kakav predmet.

Upravo bi osobe s intelektualnim teškoćama trebale biti s osobitom brižnošću od strane društvenih struktura zaštićene od svakog oblika nasilja. Društvo je dužno bdjeti nad njihovim dostojanstvom, posebice kad je riječ o seksualnom zlostavljanju i iskorištavanju. Briga zajednice i zaštita osoba s intelektualnim teškoćama podrazumijeva također način i metode zaštite. To automatski povlači za sobom pitanje o ćudoredno dopuštenim sredstvima kako osobe s intelektualnim teškoćama zaštiti i obraniti od seksualnog iskorištavanja. Moralisti dvoje, nisu jedinstvenog stava zato što su doista brojne i raznolike situacije koje otežavaju 
postizanje jednoglasnog ćudorednog stava. Najteže pitanje sadržano je u dvojbi, odnosno prosudbi situacija u kojima bi eventualno pribjegavanje kontracepciji bilo ipak moralno dopušteno ili nedopušteno.

U prethodnom smo poglavlju zaključili kako je nasilje nad sposobnošću rađanja učiniti nekoga kirurškom ili bilo kojom drugom metodom trajno neplodnim nedopustivo, jer je to povreda integriteta i dostojanstva ljudske osobe. No, ipak se dvoji u vezi s privremenom „zaštitom od rađanja“ u nekim uistinu specifičnim situacijama, kao što je primjerice pretpostavka silovanja, nakon čega bi osoba mogla zatrudnjeti. Može li se u takvim rijetkim i izvanrednim situacijama govoriti o dopuštenom uzimanju kontraceptivnih sredstava? Tu je riječ o privremenom, odnosno povremenom sprječavanju začeća.

Pio XII. je, ne govoreći o načinu, proglasio dopuštenim da osobe koje zbog nasljedne mane nisu sposobne ponašati se „sukladno zdravomu ljudskomu razumu“ (comportarsi umanamente) niti su sposobne sklopiti brak ili, ako je kasnije postao nesposoban, zahtijevati ono na što u sklopljenom braku ima pravo, takve se može spriječiti u rađanju novog života (Faggioni, 2007, 120). ${ }^{1}$

S obzirom na dopuštenost sredstva u svrhu obrane od psihološki vrlo teških posljedica nakon trudnoće koja je plod nasilnog seksualnog čina, posebice ako se tu problematiku promatra posve izdvojeno, katolički moralisti tvrde kako je dopušteno, barem načelno, pribjeći sredstvu koje bi spriječilo začeće. U tom se slučaju ne namjerava slobodne seksualne čine lišiti njihove prokreativne dimenzije, nego je jedina namjera i cilj intervenirati preventivno kako bi se onemogućilo da dođe do prirodnih posljedica abuzivnog, nasilnog čina. Zapravo se nasilje na neki način „produžava“ u tijelu žene kroz spermu koja je sposobna oploditi jajašce, te stoga spriječiti da dođe do začeća znači ustvari spriječiti da zlodjelo silovatelja dostigne ekstremne posljedice. Posegnuti za sprječavajućim sredstvom poprima primarno obrambeni karakter i oslobađa od zastrašujuće i ponižavajuce trudnoće koja je posljedica nasilnog čina. Prevenirati kontraceptivnim sredstvom samo je u indirektnom smislu antiprokreativni čin. Dakle, ni u kojem slučaju nije riječ o činu koji bi bio nadahnut mentalitetom „protiv života“ niti se protivi trudnoći kao takvoj, koja je u sebi dobra, nego se posezanjem za kontracepcijskim sredstvom preventivno ustaje protiv i štiti od eventualnih posljedica nepravednog napada na tijelo i osobno dostojanstvo žene.

Ustvari, zloća kontracepcije u formalnom smislu proizlazi iz volje, odnosno ćudoredno se vrjednovanje temelji na slobodnom opredjeljenju supružnikâ koji se opiru prirodnoj svrhovitosti bračnih čina i zato svojevoljnom intervencijom sprječavaju da dođe do začeća novog ljudskog života. Dakle, ako volja za sprječavanjem začeća uopće nije prisutna, onda se ni ne može govoriti o „kontracepcijskoj grješnosti“. U enciklici Humanae vitae nema protivljenja liječenju koje je

1 Auor navodi citat iz govora pape Pia XII. sudionicima Prvog međunarodnog simpozija medicinske genetike 7. rujna 1953.: »quando una persona colpita da tare ereditarie, non è capace di comportarsi umanamente né, per conseguenza, di contrarre matrimonio; oppure quando più tardi è divenuto incapace di rivendicare, con un atto libero, il diritto acquisito con un matrimonio valido, gli si può impedire in maniera lecita di procreare una nuova vita.« 
nužno zbog bolesti tijela (primjerice rak maternice ili rak prostate), ako se čak predviđa da će to liječenje djelovati sterilizirajuće na reproduktivne potencijale pacijenta, pod uvjetom da taj čin protiv plodnosti nije izravno namjeravan (HV 5). To ne znači, naravno, da se materijalne komponente ljudskog čina mogu u ćudorednom smislu smatrati irelevantnim, jer bi se to direktno protivilo nauku o višestrukoj kompleksnosti ljudskog čina, nego to znači da se ne može svaki postupak koji fizički sprječava moguće začeće smatrati identičnim onomu ćudoredno grješnomu činu kontracepcije o kojem se govori u enciklici Humanae vitae.

To rješenje koje smo predstavili čini se primjenjivim i obranjivim, barem u teorijskom smislu, i kada je riječ o sličnim situacijama koje proživljavaju osobe s intelektualnim teškoćama. Treba ipak biti svjestan kako predloženo rješenje krije u sebi veliku praktičnu ograničenost i rizičnost, koja nipošto nije hipotetična. Naime, gledano sveobuhvatnije, sama intervencija da ne dođe do začeća neće obraniti osobu s intelektualnim teškoćama od agresije bezobzirnog silovatelja, nego samo od posljedica nasilničkog čina. Isto tako, ako osoba s intelektualnim teškoćama bude lišena svoje sposobnosti rađanja, nju se automatski čini još ranjivijom zato što će odgajatelji i svi oni koji su zaduženi bdjeti nad njezinom sigurnošću u novonastaloj situaciji biti manje oprezni u svojoj dužnosti da je zaštite te će na taj način možda potaknuti nasilnike na dodatna poniženja. Moralisti koji smatraju prihvatljivom primjenu sredstava koja osobe s intelektualnim teškoćama lišavaju sposobnosti začeća govore kako se ta dopuštenost odnosi isključivo na situacije u kojima su osobe s intelektualnim teškoćama ekstremno izložene nasilju. Primjena se treba također ograničiti isključivo za foro interno, jer je nemoguće za takve slučajeve definirati opće prihvatljive moralne i pravne norme.

Potrebno je također naglasiti kako ni u kojem slučaju, ako osoba s intelektualnim teškoćama zatrudni, nije dopušteno pribjeći pobačaju, bez obzira na situaciju, uvjetovanost i motivaciju. To isto vrijedi za spiralu kao i za „pilulu za dan poslije“" (službeni naziv $R U$ 486; komercijalni naziv ellaOne). Ta se pilula uzima dva uzastopna dana nakon nezaštićenog spolnog čina i ako je došlo do začeća ona će djelovati abortivno tako što će spriječiti ugnježđenje embrija na stjenku maternice. Ta je pilula moralno neprihvatljiva i zato što se uzima uvijek s abortivnom nakanom, premda se ne može znati je li se pobačaj uistinu dogodio. Neki to sredstvo nazivaju „hitnom kontracepcijom“, iako nije riječ o sprječavanju začeća.

Nažalost, ta su sredstva jedino što društvo nudi preko zdravstvenih ustanova, kada je riječ o brutalnom seksualnom nasilju na ženi, što je duboko ponižavajuće i protivi se dostojanstvu ljudske osobe. Takav čin zaslužuje još veću moralnu osudu i zasluženu sudsku kaznu kada se nasilnik iživljava na osobi s intelektualnim teškoćama. 


\section{Zaključak}

Osobe s umanjenim mentalnim sposobnostima trebaju, možda čak više nego drugi bolesnici, našu pažnju, naklonost, razumijevanje i ljubav. Takve se osobe ne može ostaviti same i bez stručne asistencije u teškoj zadaći sučeljavanja sa svakodnevnom životnom stvarnošću. Doista je potrebno izbjegavati sve spekulacije i odreći se svih sebičnih interesa pojedinaca, zajednice i cijelog društva opredjeljujući se za autentično promicanje dostojanstva i što kvalitetnijeg života osoba s intelektualnim teškoćama. Nedopustivo je uskraćivati im skrb, zaštitu i život dostojan čovjeka zato što je to u socijalnom i financijskom smislu zahtjevnije. Standard i kvaliteta života jednog društva mjeri se prema promoviranju, skrbi i zaštiti onih mentalno i fizički najranjivijih i najslabijih u društvu. Taj odnos postaje zrcalo u kojem se ogleda koliko društvo u čijoj sredini žive poštuje njihovo ljudsko dostojanstvo koje se temelji na svetopisamskoj istini da je svaki čovjek stvoren na sliku Božju.

Ne samo osobe s intelektualnim teškoćama težeg nego i lakšeg stupnja trebaju različite oblike pomoći kako bi što uspješnije svladale svakodnevne životne poteškoće. To se posebice odnosi na spolno i čuvstveno sazrijevanje osoba s intelektualnim teškoćama. Polazište autentičnog čuvstvenog i spolnog odgoja osoba s intelektualnim teškoćama je činjenica da i oni imaju potrebu za ljubavlju, da žele ljubiti i biti ljubljeni. Unatoč svojim razvijenim tjelesnim spolnim sposobnostima, osobe s intelektualnim teškoćama u čuvstvenom su smislu manje ili više ograničene, posebice kada je riječ o uspostavljanju i održavanju zrelog čuvstvenog odnosa te preuzimanju odgovornosti u spolnom i čuvstvenom partnerskom odnosu.

Zbog svojih umanjenih intelektualnih sposobnosti te su osobe spolno i čuvstveno ranjivije i izloženije. Ćudoredno su neprihvatljive sve intervencije usmjerene protiv seksualnog integriteta osoba s intelektualnim teškoćama. To se odnosi prvenstveno na kiruršku i farmakološku sterilizaciju osoba s intelektualnim teškoćama, bez obzira na motivaciju i razloge te intervencije. O kontracepciji većina moralista smatra da je ćudoredno prihvatljiva primjena kontraceptivnih sredstava kod osoba s intelektualnim teškoćama ako su izložene nasilju. Budući da je gotovo nemoguće za takve slučajeve definirati opće prihvatljive moralne i pravne norme, ta dopustivost vrijedi isključivo za izvanredne, ekstremne i rijetke situacije izloženosti seksualnomu nasilju.

Svaka osoba s invaliditetom, bez obzira na njezine tjelesne ili intelektualne razvijenosti i ograničenja, osvjetljava još jačim svjetlom misterij ljudskog bića u svekolikom njegovu dostojanstvu i veličini. Međutim, u susretu s osobom koja je u tijelu, u svojoj psihi ili razumu uskraćena za jednu ili više sposobnosti, otkrivamo također tajnu ljudske nesavršenosti i ograničenosti. Svi smo pozvani da se što više približimo tim osobama, kako bismo što bolje upoznali i zavoljeli sve njihove zakržljale, zapretene i nerazvijene sposobnosti i ograničenja, nastojeći ih svojim stručnim radom, strpljivošću i ljubavlju ublažiti. 


\section{Literatura:}

An. (1998). Körper und Sexualität: Sexualität und geistige Behinderung. Frankfurt: Pro familia Deutsche Gesellschaft für Familienplanung, Sexualpädagogik und Sexualberatung.

Bratković, Daniela (2000). Edukacija o spolnosti osoba s mentalnom retardacijom. Zagreb: Hrvatski savez udruga za osobe s mentalnom retardacijom.

Bratković, Daniela; Bilić, Marija (2004). Stavovi prema spolnosti osoba s mentalnom retardacijom. U: Vesna Đurek (ur.), Zbornik radova 5. međunarodnog seminara: Dobra edukacijsko-rehabilitacijska praksa za 21. stoljeće (str. 189-200), Trakošćan: Savez defektologa Hrvatske.

Castelli, Giuseppe (2005). Sessualità \& disabilità. U: Giuseppe Castelli i Vittore Mariani (ur.), L'educazione sessuale delle persone disabili. Guida per genitori \& operatori (str. 13-179). Milano: Ares.

Dixon, Hilary (1990). Anch'io...: L'educazione alla sessualità nell'handicappato. Trento: Erickson.

Faggioni, Maurizio (2007). Disagio della mente e disagio del corpo. U: Dignità e diritti della persona con handicap mentale. Atti del Simposio promosso dalla Congregazione per la Dottrina della Fede (str. 111-123). Città del Vaticano: Libreria Editrice Vaticana.

Henry, Paolo (1999). Il problema della prevenzione delle gravidanze indesiderate nei servizi di salute mentale. U: Fabio Veglia (ur.), Handicap e sessualità: il silenzio, la voce, la carezza: Dal riconoscimento di un diritto al primo centro comunale di ascolto e consulenza (str. 61-68). Milano: FrancoAngeli.

HV. Humanae vitae. U: Pavao VI., Humanae vitae: Ljudski život: Enckilika o ispravnoj regulaciji poroda. Zagreb: Kršćanska sadašnjost.

Ivan Pavao II. (2007). Messaggio del Santo Padre. U: Dignità e diritti della persona con handicap mentale. Atti del Simposio promosso dalla Congregazione per la Dottrina della Fede (str. 17-20). Città del Vaticano: Libreria Editrice Vaticana.

Lucas Lucas, Ramón (2007). Bioetika za svakoga. Split: Verbum.

Mariani, Vittore (1992). L'handicappato mentale adulto. Torino: Elledici.

Mariani, Vittore (2005). Linee pedagogiche. U: Giuseppe Castelli i Vittore Mariani (ur.), L'educazione sessuale delle persone disabili. Guida per genitori \& operatori (str. 183324). Milano: Ares.

Ortland, Barbara (2008). Behinderung und Sexualität. Grundlagen einer behinderungsspezifischen Sexualpädagogik. Stuttgart: Kohlhammer W.

Piana, Giannino (1999). Etica, handicap e sessualità. U: Fabio Veglia (ur.), Handicap e sessualità: il silenzio, la voce, la carezza: Dal riconoscimento di un diritto al primo centro comunale di ascolto e consulenza (str. 152-158). Milano: FrancoAngeli.

Reynolds, Kate E. (2014). Sessualità e autismo: Guida per genitori, caregiver e educatori. Trento: Erickson.

Rovatti, Francesco (2016). Sessualità e disabilità intellettiva: Guida per caregiver, educatori e genitori. Trento: Erickson. 


\section{Morally Unacceptable Interventions Into the Sexual Functioning of Persons with Intellectual Disabilities}

\section{Ante Komadina*}

\section{Summary}

The article examines, in the light of Christian anthropology and ethics, certain complex situations with reference to the sexual and emotional life of persons with intellectual disabilities. These are life situations with which the parents and caregivers of persons with intellectual disabilities are faced in daily life. The topic is unavoidable also in the broader social context. „Quandaries" are discussed from the perspective of Christian moral teaching, particularly with regard to surgical sterilization of persons with intellectual disabilities which is done in favour of sexual liberalism and to avoid possible inherited pathological states. An increase in sexual violence raises the issue of the "protection" of persons with intellectual disabilities with the aid of contraceptives. In discussing this issue the author highlighted some contradictory positions, as well as the existence of borderline situations and all quandaries which affect them. The author concludes that a socially aware civil society should provide each physically, and especially mentally, undeveloped person with adequate care and protection, regardless of how demanding this may be socially and economically. The quality of a society is measured by its engagement in the care of its members, especially in regard to persons in society responsible for the weakest and those most in need of our help.

Key words: persons with intellectual disabilities, sexual and emotional life, surgical sterilization, contraception

* Ante Komadina, Ph.D., Assistant Professor, Catechetical-Theological Institute, Mostar. Address: Zagrebačka 5A, 88000 Mostar, Bosnia and Herzegovina. E-mail: caritas-mostar@tel.net.ba 